\title{
Fabrication of an In-pipe Microrobot Movable in Sheep's Small Intestine
}

\author{
○学 宮嶋 克典 (日本工大 (院)） 学 笠井 洋平（日本工大） 正 加藤 重雄（日本工大）
}

Katsunori MIYAJMA,Nippon Institute of Technology,Miyashiro,Saitama 345-8501

Youhei KASAI,Nippon Institute of Technology

Shigeo KATO, Nippon Institute of Technology

\begin{abstract}
This paper presents the fabrication of a new in-pipe microrobot movable in sheep's small intestine. The microrobot is made by three flexible rubber bellows which are $5 \mathrm{~mm}$ in diameter and $20 \mathrm{~mm}$ long. The microrobot is connected thin tubes which are $1 \mathrm{~mm}$ in inner diameter, $1000 \mathrm{~mm}$ long and feed pneumatic and vacuum pressure to the microrobot. The microrobot is equipped eight thin friction-rings which are located at both ends of the bellows, and the front and the rear ends of the microrobot. The friction-ring are $7 \mathrm{~mm}$ in outer diameter and $0.3 \mathrm{~mm}$ thin made of vinyle chloride for the acrylic pipe and made of rubber with small warts for the sheep's small intestine. The maximum speed of $40 \mathrm{~mm} / \mathrm{s}$ was obtained at the pneumatic pressure of $0.11 \mathrm{MPa}$, the vacuum pressure of $-0.08 \mathrm{MPa}$, and the pulse width time of 0.05 seconds in the acrylic pipe and also $9 \mathrm{~mm} / \mathrm{s}$ was obtained in the sheep's small intestine.
\end{abstract}

Keywords: In-pipe, Microrobot, Sheep's small intestine, Friction-ring

\section{1.はじめに}

生体内の血管や腸などの治療や検査などができる管内 走行ロボットが要求されている．筆者らは最小でも内径

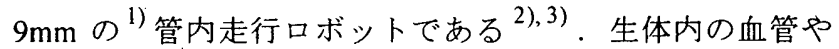
腸などは内径が小さいため,より小さな管内を走行できる ロボットが必要だと考える. 今回, 内径 $7 \mathrm{~mm}$ の管内を走 行ができ, また羊腸管内も走行できる, ベローズを 3 つ連 結させ動力を空気圧とした空気圧駆動式による羊腸管内 走行可能な小径管内マイクロロボットを試作した.

\section{2.構造}

ゴムベローズを 3 つ連結させ,ベローズの伸縮と摩擦リ ングの抵抗により走行を行う管内マイクロロボットを制 作した。管内マイクロロボットの構造を図 1 に示す。ゴム ベローズ (外径 $5 \mathrm{~mm}$, 内径 $2 \mathrm{~mm}$, 長さ $20 \mathrm{~mm}$, 山の数 8 ヶ)を $3 つ$ 連結させた管内マイクロロボット(長さ $60 \mathrm{~mm}$, 山の数 22 ケ）に, 空気圧を送り込み, 吸い出すシリコン チューブ（外径 $2 \mathrm{~mm}$, 内径 $1 \mathrm{~mm}$, 長さ $1000 \mathrm{~mm}$ ) と, ベ ローズ内に供給するためのシリコンチューブ（外径 $1 \mathrm{~mm}$, 内径 $0.5 \mathrm{~mm}$ ）を取り付け, ベローズの谷に塩化ビニール樹 脂製の摩擦リング（外径 $7 \mathrm{~mm}$, 内径 $1.5 \mathrm{~mm}$ ，厚さ $0.3 \mathrm{~mm}$ ) を，走行補助のため進行方向に円錐状に取り付けた。なお 羊腸内走行では、大きな摩擦力を必要とするので天然ゴム 製の摩擦リング (外径 $7 \mathrm{~mm}$, 内径 $1.5 \mathrm{~mm}$, 凸厚さ $0.5 \mathrm{~mm}$, 凹厚さ $0.3 \mathrm{~mm}$ )を 1 つのベローズの頭尾に装着した. 先頭 のベローズにバネ（直径 $5 \mathrm{~mm}$, 線径 $0.3 \mathrm{~mm}, 6$ 巻き）を 方向性の向上と, 伸縮の補助する目的で取り付けた。管内 マイクロロボットの動作順序を図 2 に示す. エアコンプレ ッサ及び真空ポンプを利用し，空気の吸入・排出を繰り返 すことにより走行を可能にする.実験に使用した 2 種類の 摩擦リングを図 3 に示す。

\section{3.実験装置}

実験装置を図 4 に示す. 管内マイクロロボットを走行さ せるための信号を発振するパルス制御回路は, ポケットコ ンピュータを用いて制御する.動力源となる空気圧は, 工 アコンプレッサから出され, エアフィルタにより空気は浄 化され，レギュレータにより空気圧を調節され，ポケット コンピュータで制御されたパルス制御回路の信号を受け た電磁弁を通して管内マイクロロボットを動かす.また電 磁弁の排出口に真空ポンプをつなぎ, ゴムベローズの縮み を速める。

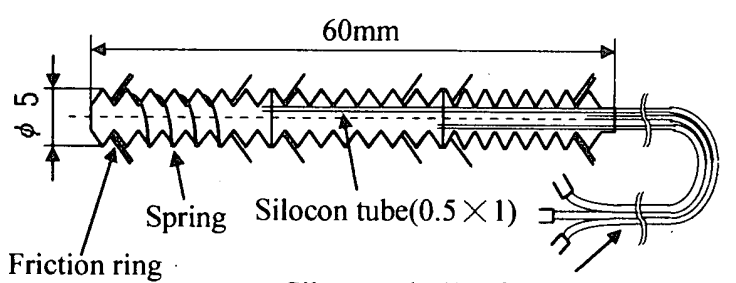

Silocon tube $(1 \times 2), 1000 \mathrm{~mm}$ long

Fig.1 Structure of the microrobot

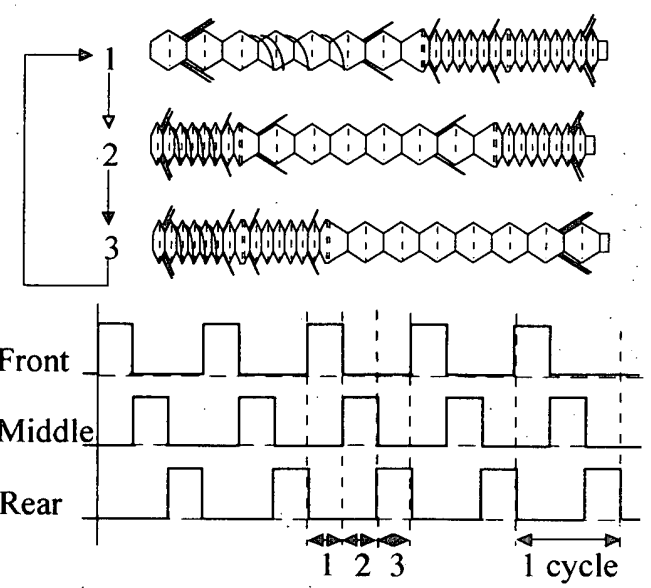

Fig.2 Time chart of the microrobot

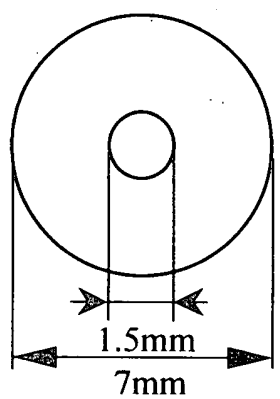

$0.3 \mathrm{~mm}$ thickness Vinyl chloride

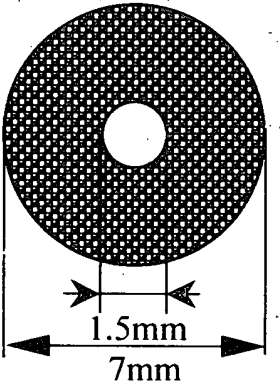

$0.4 \mathrm{~mm}$ thickness Natural rubber
Fig.3 Friction ring 


\section{4.実覧方法}

管内マイクロロボットが走行するために必要である摩 擦リングの摩擦力をフォースゲージで測定する.管内マイ クロロボットを内径 $7 \mathrm{~mm}$ のアクリル管内を $100 \mathrm{~mm}$ 水平 方向に走行させた．そのときの走行速度を測定する. ゴム ベローズを伸縮させるためにパルス幅を変化させた。この ときポケットコンピュータを用いてパルス幅を $0.05[\mathrm{~s}]$ か ら $0.60[\mathrm{~s}]$ まで変化させた。 羊腸内走行では塩漬けされて いる羊腸をいったん水に浸け，よく伸びるようにした．水 に浸けることによりぬめりがでて, 水分も与えることがで きるので, 障害物のない腸内部に近い状態にすることがで きた。そこで，内径 $7 \mathrm{~mm}$ のアクリル管内に羊腸を管内側 に接した状態にし，そのときの走行速度をアクリル管内走 行実験と同様の方法で測定する。

\section{5.実臨結果}

\section{1 摩擦力の測定}

塩化ビニール樹脂製の摩擦リングの摩擦力は, アクリル 管内において順方向 1 枚当たり $0.05[\mathrm{~N}]$, 全体（8 枚）で $0.4[\mathrm{~N}]$ であった。逆方向では 1 枚当たり $0.09[\mathrm{~N}]$, 全体（8 枚）で $0.75[\mathrm{~N}]$ であった。 天然ゴム製のいぼ付き摩擦リン グは，羊腸内において順方向で 1 枚当たり $0.05[\mathrm{~N}]$ ，全体 (6枚)で $0.31[\mathrm{~N}]$ であった.逆方向では 1 枚当たり $0.09[\mathrm{~N}]$, 全体（6 枚）で $0.56[\mathrm{~N}]$ であった。

5.2 アクリル管内走行実験

$100 \mathrm{~mm}$ 走行時の平均速度を図 5 に示す。パルス幅が短 く加圧が高いほど管内マイクロロボットの速度は, 速くな っていることが分かった，しかし，加圧が低いと伸縮がし つかり行えないため, パルス幅が短くても速度が速くなら なかったと考えられる．最高速度はパルス幅 $0.05[\mathrm{~s}]$ ，加 圧 $0.11[\mathrm{MPa}]$, 真空圧 $0.08[\mathrm{MPa}]$ の場合で $40.4[\mathrm{~mm} / \mathrm{s}]$ であっ た.

\section{3 羊腸管内走行実験}

$100 \mathrm{~mm}$ 走行時の平均速度を図 6 に示す.アクリル管内 とは違い各加圧, パルス幅 0.08 [s] 頂点とし, その後速 度は落ちていった．また，パルス幅が短いと速度が遅いの かは, 伸縮が速過ぎたため羊腸内の滑りで摩擦リングの役 割が十分ではなかったためと考えられる.最高速度はパル ス幅 $0.08[\mathrm{~s}]$, 加圧 $0.11[\mathrm{MPa}]$, 真空圧 $0.08[\mathrm{MPa}]$ の場合で $9.1[\mathrm{~mm} / \mathrm{s}]$ であった。

6.まとめ

(1)外径 $5 \mathrm{~mm}$, 長さ $20 \mathrm{~mm}$ のゴムベローズを 3 つ連結させ, ベローズの伸縮と摩擦リングの抵抗により走行を行う, 内 径 $7 \mathrm{~mm}$ の管内走行可能な管内マイクロロボットを試作し た

(2)アクリル管内走行時, パルス幅 0.05 [s], 加圧 0.11 [MPa], 真空圧 $0.08[\mathrm{MPa}] に お い て ~ 40.4[\mathrm{~mm} / \mathrm{s}]$ 方得られた。

(3)羊腸管内走行時, $0.08[\mathrm{~s}]$, 加圧 $0.11[\mathrm{MPa}]$, 真空圧 $0.08[\mathrm{MPa}]$ において $9.1[\mathrm{~mm} / \mathrm{s}]$ が得られた。

\section{7.参考文献}

(1) 福本, 加藤, 真空圧駆動式ミミズロボットの走行特性, 日本機会学会東北支部第 33 期総会・講演会講演論文集, 1998,pp.57-58.

(2) 平山，加藤，空気圧駆動式人工ミミズの走行特性, 日本機会学会第 74 期通常総会講演論文集(IV), 1997-3,pp.295-296.

(3) 白川, 加藤, 斉藤, 超高速管内走行微小ロボット の試作,

日本機会学会東北支部・米沢地方講演会講演論文集, 1999-9,pp.241-242.

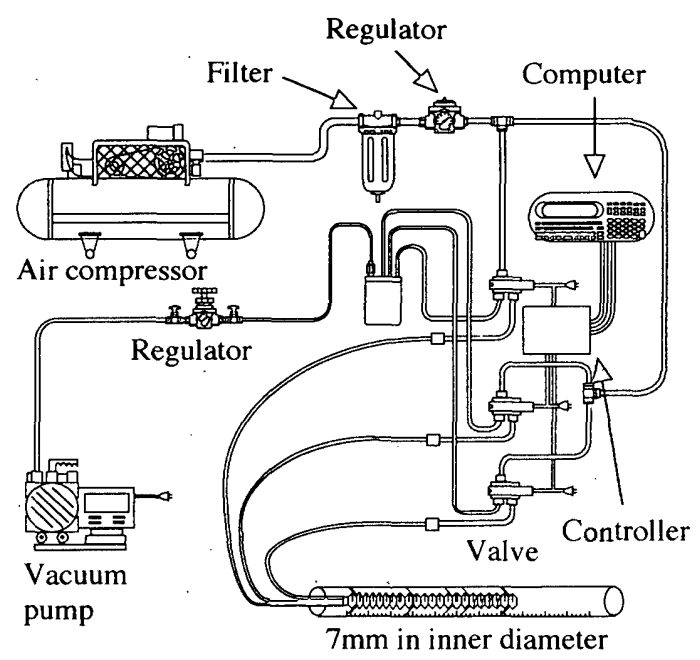

Fig.4 Experimental apparatus

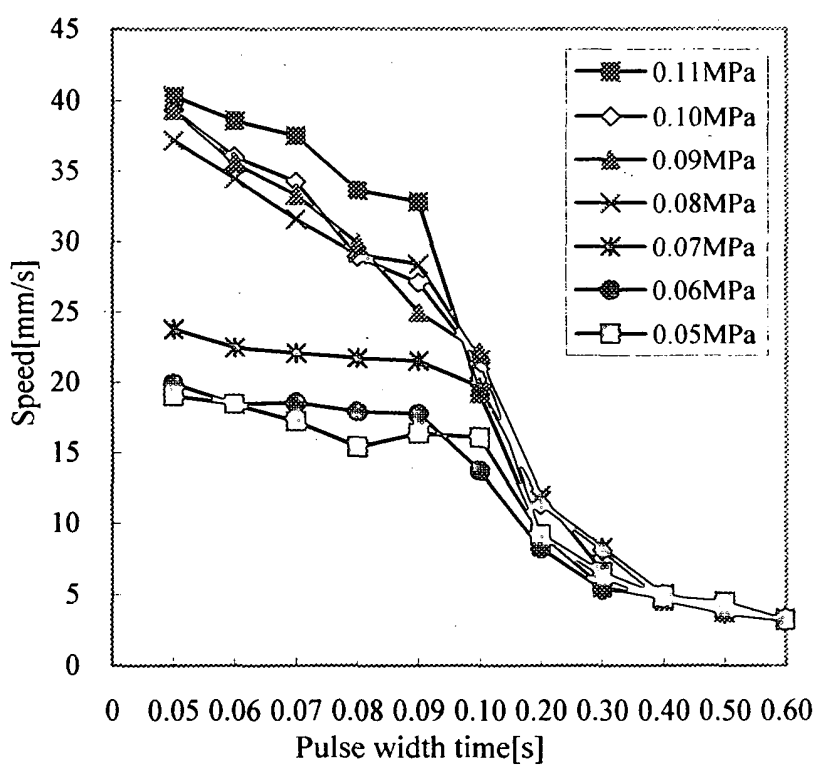

Fig.5 Speed of the microrobot (in acrylic pipe)

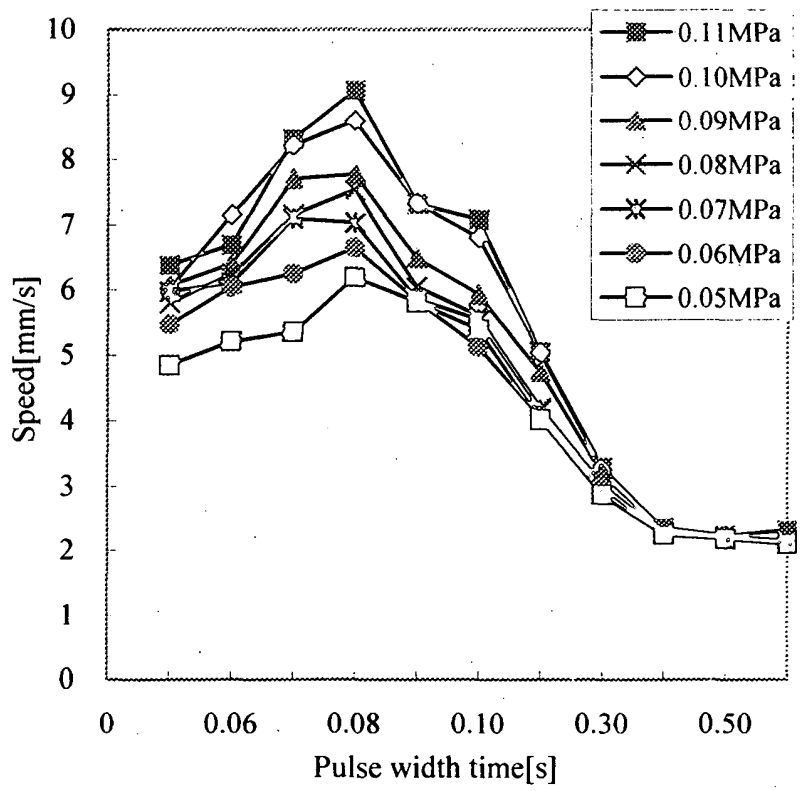

Fig.6 Speed of the microrobot (in sheep's intestine) 